\title{
Penggunaan Saksi Mahkota (Kroongetuige)dalam Pembuktian di Persidangan Terhadap Tindak Pidana Narkotika
}

\author{
Nadia Febriani, Haryadi, Dessy Rakhmawati \\ Fakultas Hukum Universitas Jambi \\ Author's email correspondence: nadiafebrianix@gmail.com
}

\begin{abstract}
ABSTRAK
Tujuan artikel ini adalah untuk mengetahui penggunaan saksi mahkota (Kroongetuige) dalam pembuktian di persidangan dan Kekuatan saksi mahkota sebagai alat bukti dalam pembuktian tindak pidana narkotika. Dengan menggunakan metode yuridis normative, Artikel ini menunjukkan penggunaan saksi mahkota (kroongetuige) dalam pembuktian di persidangan terhadap tindak pidana narkotika diterapkan untuk mencari dan mendapatkan kebenaran materil dalam perkara penyertaan, dan berkas perkara telah dipisah, serta terdapat kekurangan alat bukti keterangan saksi yang mengetahui secara terperinci tindak pidana yang dilakukan bersama-sama dan penggunaan saksi mahkota tergantung dari kebijakan hakim dan kekuatan saksi mahkota sebagai alat bukti dalam pembuktian tindak pidana narkotika mempunyai nilai kekuatan pembuktian apabila saksi mahkota dinyatakan sah sebagai alat bukti keterangan saksi dengan memberikan keterangan didepan persidangan dan telah disumpah terlebih dahulu serta keterangan yang diberikan bersesuaian dengan keterangan saksi lain maupun alat bukti lain serta ditambah dengan keyakinan hakim.
\end{abstract}

Kata Kunci: Saksi mahkota (Kroongetuige); pembuktian di persidangan; tindak pidana narkotika.

\section{ARTICLE HISTORY}

Submission: 2020-06-11

Accepted: 2020-10-07

Publish: 2020-10-10

KEYWORDS: Crown witness (kroongetuige); proof in trial; narcotics crimes.

\begin{abstract}
The purpose of this article is to study the Use of the Crown Witness (Kroongetuige) in Proof in Trials Against Narcotics Crimes. How to use the Crown Witness (Kroongetuige) in Proof in Trial Against Narcotics and How the Strength of the Crown Witness Uses Evidence in Proving Narcotics Crimes. The research method used is a normative juridical method with agreement, conceptual agreement and case access. This article discusses the use of crown witnesses (kroongetuige) in evidence in trials of narcotic crimes applied to search for and obtain material truth in inclusion cases, and forged cases posted, and also the reporting tools for complaints that are used together and the use of crowns depending the judge's policy and the power of the crown as evidence in proving narcotics crime has a value of proof power. Having fun with other statements besides evidence is also added to the judge's conviction.
\end{abstract}

\section{A. PENDAhuluan}

Penyelesaian perkara pidana dilakukan berdasarkan hukum acara pidana sebagaimana diatur dalam Undang-Undang Nomor 8 Tahun 1981 tentang Hukum 
Acara Pidana (KUHAP), ${ }^{1}$ yang memiliki rumusan sistem pembuktian tersendiri, yaitu terdapat dalam Pasal 183 sampai dengan Pasal 202 KUHAP. Pembuktian memegang peranan penting dalam proses pemeriksaan di sidang pengadilan, karena melalui proses pembuktian dapat ditentukan nasib terdakwa apakah kesalahan terdakwa patut dihukum atau sebaliknya. Salah satu cara membuktikan terdakwa bersalah atau tidak bersalah yakni dengan menghadirkan saksi, dan keterangan yang diberikan saksi merupakan salah satu alat bukti sebagaimana diatur dalam Pasal 184 KUHAP.

Adapun rumusan sistem pembuktian tersebut yakni untuk mendukung tujuan dari pada hukum acara pidana adalah untuk mencari dan mendapatkan atau setidaktidaknya mendekati kebenaran materiil.2 Tetapi tujuan akhir dari hukum acara pidana adalah untuk mencapai suatu ketertiban, ketentraman, kedamaian, keadilan serta kesejahteraan dalam masyarakat. Penerapan rumusan sistem pembuktian tersebut harus berpedoman pada asas-asas yang berlaku dalam proses peradilan pidana, seperti asas praduga tidak bersalah (presumption of innocence), dan asas persamaan di hadapan hukum (equality before the law).

Berdasarkan teori pembuktian dalam hukum acara pidana hampir semua pembuktian perkara pidana selalu didasarkan kepada pemeriksaan keterangan saksi. Ketentuan untuk menjadi saksi adalah ia harus melihat, mendengar ataupun mengalami sendiri karena apabila diketahui keterangan yang diberikan palsu maka dapat dikenai sanksi atas kesaksiannya tersebut. Saksi yang juga seorang pelaku dalam perkara yang sama dalam praktik peradilan pidana disebut dengan saksi mahkota.

Dalam proses pemeriksaan disidang pengadilan sering digunakan saksi mahkota yang kedudukan sebagai saksi dan terdakwa dalam perkara yang sama. Saksi mahkota digunakan karena dapat mengungkap fakta hukum dan fakta peristiwa karena saksi mahkota adalah orang yang mengetahui secara terperinci tentang perencanaan, persiapan, dan proses pelaksanaan sehingga terjadi tindak pidana. Tetapi belum ada peraturan perundang-undangan khusus mengenai saksi mahkota namun sering digunakan dalam proses pemeriksaan disidang pengadilan.

Pembuktian merupakan titik sentral pemeriksaan perkara di pengadilan. Pembuktian adalah ketentuan-ketentuan yang berisi penggarisan dan pedoman tentang cara-cara yang dibenarkan undang-undang membuktikan kesalahan yang didakwakan kepada terdakwa dan juga merupakan ketentuan yang mengatur alat-alat bukti yang dibenarkan undang-undang dan yang boleh dipergunakan oleh hakim untuk membuktikan kesalahan yang didakwakan. ${ }^{3}$

Sumber-sumber hukum pembuktian dalam pemeriksaan perkara pidana sebagai berikut:

1. Undang-undang;

2. Doktrin atau pendapat para ahli hukum; dan

3. Yurisprudensi/putusan pengadilan. ${ }^{4}$

1 Usman dan Andi Najemi, "Mediasi Penal di Indonesia: Keadilan, Kemanfaatan, dan Kepastian Hukumnya,"Jurnal Hukum, Vol 1 No. 1, 2018, hlm. 66.

2 Andi Hamzah, Hukum Acara Pidana Indonesia (Jakarta: Sinar Grafika, 2017), hlm. 7.

3 Bastianto Nugroho, "Peranan Alat Bukti Dalam Perkara Pidana Dalam Putusan Hakim Menurut KUHAP," Jurnal Hukum Yuridika, Vol 32 No. 1, 2017, hlm. 23.

4 Alfitra, Hukum Pembuktian Dalam Beracara Pidana, Perdata dan Korupsi Di Indonesia (Jakarta Raih Asa Sukses, 2012), hlm. 22. 
Dalam pembuktian di sidang pengadilan kegiatan pembuktian dibedakan menjadi 2 (dua) bagian yaitu:

1. Bagian kegiatan pengungkapan fakta; dan

2. Bagian pekerjaan penganalisisan fakta yang sekaligus penganalisisan hukum. ${ }^{5}$

Secara teoretis, dikenal empat macam sistem pembuktian dalam perkara pidana, yaitu sebagai berikut:

1. Sistematau teori pembuktian berdasar keyakinan hakim melulu.

Menurut Sistem ini hakim dapat menyatakan telah terbukti kesalahan terdakwa melakukan tindak pidana yang didakwakan dengan didasarkan pada keyakinannya saja, dan tidak perlu mempertimbangkan dari mana (alat bukti) dia memperoleh dan alasan-alasan yang dipergunakan serta bagaimana caranya dalam membentuk keyakinannya tersebut. Juga tidak perlu mempertimbangkan apakah keyakinan yang dibentuknya itu logis ataukah tidak logis dan sistem ini benar-benar bekerja tergantung kepada hati nurani hakim.Pada sistem ini juga membuka peluang yang besar untuk terjadi praktik penegakan hukum yang sewenang-wenang, dengan bertumpu pada alasan hakim telah yakin. ${ }^{6}$

2. Sistem atau teori pembuktian berdasar keyakinan hakim atas alasan yang logis (La Conviction Rais onnee)

Dalam sistem ini dalam membentuk dan menggunakan keyakinan hakim untuk menarik kesimpulan tentang terbuktinya kesalahan terdakwa melakukan tindak pidana didasarkan pada alasan-alasan yang logis. Dalam sistem ini walaupun alasan-alasan itu dengan menggunakan alat-alat bukti baik yang ada disebutkan dalam Undang-undang maupun diluar Undangundang, tetapi dalam hal menggunakannya dan menaruh kekuatan alat-alat bukti tersebut tergantung pada pertimbangan hakim dalam hal membentuk keyakinannya tersebut, asalkan alasan-alasan yang dipergunakan dalam pertimbangannya logis yang artinya dapat diterima oleh akal orang pada umumnya. ${ }^{7}$

3. Sistem atau teori pembuktian berdasarkan undang-undang secara positif (Positief Wettelijke Bewijs Theorie)

Sistem pembuktian positif adalah sistem pembuktian yang menyandarkan diri pada alat bukti yang telah ditentukan oleh Undang-undang. Seseorang terdakwa bisa dinyatakan bersalah melakukan tindak pidana hanya didasarkan pada alat bukti yang sah dan keyakinan hakim sama sekali diabaikan.Kelebihan sistem pembuktian ini yakni hakim akan berusaha membuktikan kesalahan terdakwa tanpa dipengaruhi oleh hati nuraninya sehingga benar-benar objektif. ${ }^{8}$

4. Sistem atau teori pembuktian berdasarkan undang-undang secara negatif (Negatief Wettelijk). ${ }^{9}$

5 Adami Chazawi, Hukum Pembuktian Tindak Pidana Korupsi, (Bandung: P.T. Alumni, 2008), hlm. 25.

6 Adami Chazawi, Hukum Pembuktian Tindak Pidana Korupsi, hlm. 25.

7 Adami Chazawi, Hukum Pembuktian Tindak Pidana Korupsi, hlm. 26.

8 Alfitra, Hukum Pembuktian Dalam Beracara Pidana, hlm. 28.

9 Susanti Ante, "Pembuktian Dan Putusan Pengadilan Dalam Acara Pidana," Lex Crimen, Vol 2 No. 2, 2013, hlm. 100. 
Dalam sistem pembuktian negatif hakim di dalam mengambil keputusan tentang salah atau tidaknya seorang terdakwa terikat oleh alat bukti yang ditentukan oleh Undang-undang dan keyakinan (nurani) hakim sendiri. Ada dua hal yang merupakan syarat untuk membuktikan kesalahan terdakwa yakni adanya alat bukti yang sah yang telah ditetapkan oleh Undang-undang dan adanya keyakinan (nurani) dari hakim berdasarkan bukti-bukti hakim meyakini kesalahan terdakwa. ${ }^{10}$

Indonesia menganut Sistem atau teori pembuktian berdasarkan undangundang secara negatif (Negatief Wettelijk) dalam proses pembuktian perkara pidana dilihat dari Pasal 183 KUHAP menyatakan sebagai berikut: "Hakim tidak boleh menjatuhkan pidana kepada seorang kecuali apabila dengan sekurang-kurangnya dua alat bukti yang sah ia memperoleh keyakinan bahwa suatu tindak pidana benar-benar terjadi dan bahwa terdakwalah yang bersalah melakukannya".

Pembuktian memegang peranan penting dalam proses pemeriksaan di sidang pengadilan oleh karenanya diperlukan alat bukti untuk membuktikan terdakwa bersalah atau tidak bersalah. Dalam KUHAP macam-macam alat bukti diatur dalam Pasal 184 Ayat (1) KUHAP, yaitu:

\section{a. Keterangan Saksi}

Dalam Pasal 1 angka 26 KUHAP Saksi adalah orang yang dapat memberikan keterangan guna kepentingan penyidikan, penuntutan dan peradilan tentang suatu perkara pidana yang ia dengar sendiri, ia lihat sendiri dan ia alami sendiri. Dalam Putusan Mahkamah Konstitusi Nomor 65/PUU-VIII/2010 makna saksi diperluas yaitu: "orang yang dapat memberikan keterangan dalam rangka penyidikan, penuntutan, dan peradilan suatu tindak pidana yang tidak selalu ia dengar sendiri, ia lihat sendiri dan ia alami sendiri".

Keterangan Saksi merupakan salah satu alat bukti dalam perkara pidana yang berupa keterangan dari saksi mengenai suatu peristiwa pidana yang ia dengar sendiri, ia lihat sendiri dan ia alami sendiri dengan menyebut alasan dari pengetahuannya itu yang diatur dalam Pasal 1 angka 27 KUHAP.

Syarat-syarat yang harus dipenuhi agar alat bukti keterangan saksi mempunyai kekuatan dalam pembuktian:

a) Keterangan saksi yang dinyatakan di sidang pengadilan harus mengenai peristiwa pidana yang di dengar, di lihat, dan di alami sendiri, ketentuan ini di atur dalam Pasal 1 Angka 27 KUHAP.

b) Sebelum memberikan keterangan saksi wajib mengucapkan sumpah atau janji menurut cara agamanya bahwa akan memberikan keterangan yang sebenar-benarnya, ketentuan ini di atur dalam Pasal 160 Ayat (3) KUHAP.

c) Keterangan saksi harus dinyatakan di sidang pengadilan,ketentuan ini di atur dalam Pasal 185 Ayat (1) KUHAP.

d) Keterangan seorang saksi saja dianggap tidak cukup, agar mempunyai kekuatan pembuktian maka harus ditambah dan

10 Alfitra, Hukum Pembuktian Dalam Beracara Pidana, hlm. 29. 
dicukupi dengan alat bukti lainnya, ketentuan ini di atur dalam Pasal 185 Ayat (2) KUHAP.

e) Keterangan para saksi yang dihadirkan dalam sidang pengadilan mempunyai hubungan atau keterkaitan serta saling menguatkan tentang kebenaran suatu keadaan atau kejadian tertentu, ketentuan ini di atur dalam Pasal 185 Ayat (4) KUHAP.

Dalam menilai kebenaran keterangan seorang saksi, hakim harus dengan sungguh-sungguh memperhatikan hal-hal sebagai berikut sesuai diatur dalam Pasal 185 Ayat (6) KUHAP:

a. persesuaian antara keterangan saksi satu dengan yang lain;

b. persesuaian antara keterangan saksi dengan alat bukti lain;

c. alasan yang mungkin dipergunakan oleh saksi untuk memberi keterangan yang tertentu;

d. cara hidup dan kesusilaan saksi serta segala sesuatu yang pada umumnya dapat mempengaruhi dapat tidaknya keterangan itu dipercaya.

Pada Pasal 185 ayat (7) KUHAP Keterangan dari saksi yang tidak disumpah meskipun sesuai satu dengan yang lain, tidak merupakan alat bukti, namun apabila keterangan itu sesuai dengan keterangan saksi yang disumpah, dapat dipergunakan sebagai tambahan alat bukti sah yang lain.

Orang-orang yang tidak dapat didengar keterangannya dan dapat mengundurkan diri tercantum dalam Pasal 168 KUHAP yaitu:

a. Keluarga sedarah atau semenda dalam garis lurus ke atas atau ke bawah sampai derajat ketiga dari terdakwa atau yang bersama-sama sebagai terdakwa;

b. Saudara dari terdakwa atau yang bersama-sama sebagai terdakwa, saudara, saudara ibu atau saudara bapak, juga mereka yang mempunyai hubungan karena perkawinan dan anak-anak saudara terdakwa sampai derajat ketiga;

c. Suami atau istri terdakwa meskipun sudah bercerai atau yang bersama-sama sebagai terdakwa.

Mereka tercantum dalam Pasal 168 KUHAP, boleh didengar sebagai saksi sebagaimana diatur oleh Pasal 169 KUHAP yang menyatakan:

(1) Dalam hal mereka sebagaimana dimaksud dalam Pasal 168 menghendakinya dan penuntut umum serta terdakwa secara tegas menyetujuinya dapat memberi keterangan dibawah sumpah;

(2) Tanpa persetujuan sebagai dimaksud dalam Pasal (1), maka diperbolehkan memberi keterangan tanpa sumpah.

\section{b. Keterangan Ahli}

Dalam Pasal 1 angka 28 KUHAP Keterangan ahli adalah keterangan yang diberikan oleh seorang yang memiliki keahlian khusus tentang hal yang diperlukan untuk membuat terang suatu perkara pidana guna kepentingan pemeriksaan. Apabila hal itu tidak diberikan pada waktu pemeriksaan oleh penyidik atau penuntut umum maka pada 
pemeriksaan disidang, diminta untuk memberikan keterangan dan dicatat dalam berita acara pemeriksaan. Keterangan tersebut diberikan setelah ia mengucapkan sumpah atau janji dihadapan hakim.

Seorang ahli dalam memberikan keterangan harus mengucapkan sumpah atau janji terlebih dahulu terdapat dalam Pasal 179 yang menyatakan:

(1) Setiap orang yang diminta pendapatnya sebagai ahli kedokteran kehakiman atau dokter atau ahli lainnya wajib memberikan keterangan ahli demi keadilan.

(2) Semua ketentuan tersebut di atas untuk saksi berlaku juga bagi mereka yang memberikan keterangan ahli, dengan ketentuan bahwa mereka mengucapkan sumpah atau janji akan memberikan keterangan yang sebaik-baiknya dan yang sebenarnya menurut pengetahuan dalam bidang keahliannya.

Perlu diperhatikan bahwa KUHAP membedakan keterangan seorang ahli di pengadilan sebagai alat bukti "keterangan ahli" (Pasal 186 KUHAP) dan keterangan ahli secara tertulis di luar sidang pengadilan sebagai alat bukti "surat". Apabila keterangan diberikan pada waktu pemerikaan oleh penyidik atau penuntut umum, yang dituangkan dalam suatu bentuk laporan, dan dibuat dengan mengingat sumpah sewaktu ia menerima jabatan atau pekerjaan, maka keterangan ahli tersebut sebagai alat bukti surat.

\section{c. Surat}

Menurut Asser-Anema surat merupakan segala sesuatu yang mengandung tanda-tanda bacaan yang dapat dimengerti yang dimaksudkan untuk mengeluarkan isi pikiran. ${ }^{11}$

Surat sebagai alat bukti sah, macam-macam surat diatur dalam Pasal 187 KUHAP yang berbunyi:

Surat sebagaimana tersebut pada Pasal 184 Ayat (1) huruf c, dibuat atas sumpah jabatan atau dikuatkan dengan sumpah, adalah:

a. berita acara dan surat lain dalam bentuk resmi yang dibuat oleh pejabat umum yang berwenang atau yang dibuat di hadapannya, yang memuat keterangan tentang kejadian atau keadaan yang didengar, dilihat atau yang dialaminya sendiri, disertai dengan alasan yang jelas dan tegas tentang keterangannya itu;

b. surat yang dibuat menurut ketentuan peraturan perundangundangan atau surat yang dibuat oleh pejabat mengenai hal yang termasuk dalam tata laksana yang menjadi tanggung jawabnya dan yang diperuntukkan bagi pembuktian sesuatu hal atau sesuatu keadaan;

c. surat keterangan dari seorang ahli yang memuat pendapat berdasarkan keahliannya mengenai sesuatu hal atau sesuatu keadaan yang diminta secara resmi dari padanya;

d. surat lain yang hanya dapat berlaku jika ada hubungannya dengan isi dari alat pembuktian yang lain.

11 Alfitra, Hukum Pembuktian Dalam Beracara Pidana, hlm. 86. 


\section{d. Petunjuk}

Petunjuk adalah perbuatan, kejadian atau keadaan, yang karena persesuaiannya, baik antara yang satu dengan yang lain, maupun dengan tindak pidana itu sendiri, menandakan bahwa telah terjadi suatu tindak pidana dan siapa pelakunya sesuai diatur dalam Pasal 188 Ayat (1) KUHAP.

Petunjuk sebagaimana dimaksud dalam Pasal 188 Ayat (1) KUHAP hanya dapat diperoleh dari:

a. keterangan saksi;

b. surat;

c. keterangan terdakwa.

Rumusan tentang pengertian alat bukti petunjuk dalam Pasal 188 Ayat (1) dan Ayat (2) KUHAP, maka unsur atau syarat alat bukti petunjuk adalah:

a. Unsur pertama, adanya perbuatan, kejadian, keadaan yang bersesuaian;

b. Unsur kedua, ada 2 (dua) persesuaian, ialah;

a) Bersesuaian antara masing-masing perbuatan, kejadian dan keadaan satu dengan yang lain, maupun

b) Bersesuaian antara perbuatan, kejadian atau keadaan dengan tindak pidana yang didakwakan;

c. Unsur ketiga, dengan adanya persesuaian yang demikian itu menandakan (menjadi suatu tanda) atau menunjukan adanya 2 (dua) hal in casu kejadian, ialah:

a) Pertama, menunjukkan bahwa benar telah terjadi suatu tindak pidana, dan

b) Kedua, menunjukkan siapa pembuatnya.

d. Alat bukti petunjuk hanya dapat dibentuk melalui 3 (tiga) alat bukti, yaitu keterangan saksi, surat, dan keterangan terdakwa. ${ }^{12}$

Penilaian atas kekuatan pembuktian dari alat bukti petunjuk adalah kecermatan dan kesaksamaan berdasarkan hati nurani hakim pada waktu pemeriksaan di muka sidang yang dilakukannya dengan arif dan bijaksana, dengan demikian petunjuk menjadi sama dengan pengamatan hakim sebagai alat bukti.

\section{e. Keterangan Terdakwa}

Dalam Pasal 1 Angka 15 KUHAP terdakwa adalah seorang tersangka yang dituntut, diperiksa dan di adili di sidang pengadilan. Sedangkan keterangan terdakwa adalah apa yang terdakwa nyatakan di sidang tentang perbuatan yang telah ia lakukan atau yang ia ketahui sendiri atau ia alami sendiri sesuai diatur dalam Pasal 189 Ayat (1) KUHAP. Dan keterangan terdakwa yang diberikan diluar sidang dapat digunakan untuk membantu menemukan bukti di sidang, asalkan keterangan itu didukung oleh suatu alat bukti yang sah sepanjang mengenai hal yang didakwakan padanya.

12 Adami Chazawi, Hukum Pembuktian, hlm. 74. 
Kekuatan alat bukti keterangan terdakwa diatur dalam Pasal 189 Ayat (3) dan (4) KUHAP. Keterangan terdakwa tidak dapat digunakan untuk membuktikan kesalahan orang lain, kecuali disertai oleh alat bukti lain. Hal ini mengingatkan bahwa terdakwa dalam memberikan keterangannya tidak perlu mengucapkan sumpah atau janji, maka ia boleh menyangkal segala tuduhan karena ia tidak terikat sumpah atau janji. Penyangkalan terdakwa adalah hak terdakwa oleh sebab itu, suatu penyangkalan terhadap suatu perbuatan mengenai suatu keadaan tidak dapat dijadikan alat bukti.

Pengaturan mengenai saksi mahkota tidak dapat ditemukan di dalam KUHAP namun definisi saksi mahkota dapat ditemukan dalam Putusan Mahkamah Agung No. 2437 K/Pid.Sus/2011, yang menyatakan walaupun tidakdiberikan suatu definisi otentik dalamKUHAP mengenai Saksi mahkota(kroongetuide), namun berdasarkanperspektif empirik maka Saksi mahkotadidefinisikan sebagai saksi yang berasalatau diambil dari salah seorang tersangkaatau terdakwa lainnya yang bersamasamamelakukan perbuatan pidana, dan dalamhal mana kepada saksi tersebut diberikanmahkota. Adapun mahkota yang diberikankepada saksi yang berstatus terdakwatersebut adalah dalam bentuk ditiadakanpenuntutan terhadap perkaranya ataudiberikannya suatu tuntutan yang sangatringan apabila perkaranya dilimpahkan kepengadilan atau dimaafkan atas kesalahanyang pernah dilakukan.

Dalam Yurisprudensi Mahkamah Agung No. 1986K/Pid/1989 Tanggal 21 Maret 1990 menyatakan bahwa Jaksa Penuntut Umum diperbolehkan oleh undang-undang mengajukan mengajukan teman terdakwa yang ikut serta melakukan perbuatan pidana tersebut sebagai saksi dipersidangan Pengadilan Negeri, dengan syarat bahwa saksi ini dalam kedudukannya sebagai terdakwa, tidak termasuk dalam berkas perkara yang diberikan kesaksian (Gesplits).

Selain dalam Putusan Mahkamah Agung, Saksi Mahkota juga dikenal penggunaannya dalam Surat Edaran Kejaksaan Agung Republik Indonesia No. B69/E/02/1997 perihal Hukum Pembuktian dalam Perkara Pidana yang menyatakan:

Dalam praktek, saksi mahkota digunakan dalam hal terjadi penyertaan (deelneming), dimana terdakwa yang satu dijadikan saksi terhadap terdakwa lainnya oleh karena alat bukti yang lain tidak ada atau sangat minim. Dengan pertimbangan bahwa dalam status sebagai terdakwa, keterangannya, hanya berlaku untuk dirinya sendiri, oleh karena itu dengan berpedoman pada pasal 142 KUHAP, maka berkas perkara harus diadakan pemisahan (splitsing), agar para terdakwa dapat disidangkan terpisah, sehingga terdakwa yang satu dapat menjadi saksi terhadap terdakwa lainnya.

Menurut Syofyan Lubis, penggunaan saksi mahkota didasarkan pada prinsipprinsip tertentu yaitu dalam perkara delik penyertaan, terdapat kekurangan alat bukti dan diperiksa dengan pemisahan (Splitsing). ${ }^{13}$ Sehubungan dengan status sebagai terdakwa dan juga saksi maka tentunya akan menimbulkan tekanan atau setidaktidaknya tekanan psikologis, sehingga keterangannya dapat diragukan terlebih apabila

13 Wahyu Beny Mukti Setiyawan, "Analisis Keberadaan Saksi Mahkota Dalam Kasus Pembunuhan Nasrudin Zulkarnaen Sebagai Upaya Penegakan Hak Asasi Manusia Ditinjau Dari Kitab Undang-Undang Hukum Acara Pidana (KUHAP)," Jurnal Serambi Hukum, Vol 10 No. 02,2017 , hlm. 66 . 
di persidangan saksi-saksi tersebut semuanya mencabut keterangan yang termuat dalam berita acara pemeriksaan, baik keterangan sebagai saksi maupun terdakwa, sehingga hakim tidak memperoleh kebenaran berita acara pemeriksaan penyidik.

Pemecahan berkas perkara biasanya digunakan oleh Jaksa untuk perkaraperkara di mana tindak pidananya dilakukan secara bersama-sama. Dalam konteks ini kemudian muncul istilah saksi mahkota dimana terdakwa menjadi saksi bagi terdakwa lainnya yang pokok perkaranya sama karena tindak pidana dilakukan secara bersamasama.

Penggunaan saksi mahkota ini dilarang oleh KUHAP yang menjunjung tinggi HAM terdapat pada Putusan Mahkamah Agung Republik Indonesia Nomor 1174/K/Pid/1994 tanggal 3 Mei 1995, Putusan Mahkamah Agung Republik Indonesia Nomor 1952 /K/Pid/1994 tanggal 29 April 1995, Putusan Mahkamah Agung Republik Indonesia Nomor 1950/K/Pid/1995 tanggal 3 Mei 1995 dan Putusan Mahkamah Agung Republik Indonesia Nomor 1592/K/Pid/1995 3 Mei 1995.

Menurut Van Hamel, Pengertian Tindak Pidana yaitu: "Perbuatan manusia yang bertentangan dengan hukum, Perbuatan mana dilakukan oleh seseorang yang dapat dipertanggungjawabkan dan disalahkan kepada sipembuat, perbuatan itu harus mengandung sifat yang patut dihukum".

Menurut Moeljatno tindak pidana adalah perbuatan yang dilarang oleh suatu aturan hukum, larangan yang mana disertai sanksi berupa pidana tertentu bagi barang siapa yang melanggar aturan tersebut. Dapat juga dikatakan bahwa perbuatan pidana adalah perbuatan yang dilarang hukum dan diancam pidana asal saja dalam hal itu diingat bahwa larangan ditujukan pada perbuatan yaitu kejadian atau keadaan yang ditimbulkan oleh kelakuan orang, sedang ancaman pidananya ditujukan pada orang yang menimbulkan kejahatan. ${ }^{14}$

Menurut Moeljatno yang merupakan unsur atau elemen tindak pidana adalah:

1. Kelakuan dan akibat (perbuatan);

2. Hal ikhwal atau keadaan yang menyertai perbuatan;

3. Keadaan tambahan yang memberatkan pidana;

4. Unsur melawan hukum yang objektif;

5. Unsur melawan hukum yang subjektif. 15

Berdasarkan Undang-Undang Nomor 35 Tahun 2009 tentang Narkotika Pasal 1 angka 1 Narkotika adalah zat atau obat yang berasal dari tanaman atau bukan tanaman, baik sintetis maupun semisintetis, yang dapat menyebabkan penurunan atau perubahan kesadaran, hilangnya rasa, mengurangi sampai menghilangkan rasa nyeri, dan dapat menimbulkan ketergantungan. Dalam hal ini Tindak Pidana Narkotika adalah perbuatan yang bertentangan dengan Undang - Undang Nomor 35 Tahun 2009 Tentang Narkotika.

Dan penyertaan dalam tindak pidana narkotika terdapat dalam Pasal 1 angka 18 Undang - Undang Nomor 35 Tahun 2009 bahwa:

Permufakatan Jahat adalah perbuatan dua orang atau lebih yang bersekongkol atau bersepakat untuk melakukan, melaksanakan, membantu, turut serta melakukan, menyuruh, menganjurkan, memfasilitasi, memberi konsultasi,

14 Evi Hartanti, Tindak Pidana Korupsi (Jakarta: Sinar Grafika, 2012), hlm. 7.

15 Teguh Prasetyo, Hukum Pidana (Jakarta: Rajawali Pers, 2015), hlm. 52. 
menjadi anggota suatu organisasi kejahatan Narkotika, atau mengorganisasikan suatu tindak pidana Narkotika.

Dalam Pasal 6 Ayat (1) Undang-Undang Nomor 35 Tahun 2009 terdapat penggolongan narkotika, yaitu:

1. Narkotika Golongan I

Dalam penggolongan Narkotika, zat atau obat golongan I mempunyai potensi yang sangat tinggi mengakibatkan ketergantungan.

2. Narkotika Golongan II

Narkotika pada golongan ini adalah Narkotika yang mempunyai potensi tinggi mengakibatkan ketergantungan.

3. Narkotika Golongan III

Narkotika golongan ini adalah Narkotika yang mempunyai potensi ringan menyebabkan ketergantungan.

Tindak Pidana Narkotika diatur dalam Bab XV Pasal 111 sampai dengan Pasal 148 Undang-undang Nomor 35 tahun 2009 yang merupakan ketentuan khusus, walaupun tidak disebutkan dengan tegas dalam Undang-undang Narkotika bahwa tindak pidana yang diatur di dalamnya adalah tindak kejahatan, akan tetapi tidak perlu disanksikan lagi bahwa semua tindak pidana di dalam undang-undang tersebut merupakan kejahatan.

Berdasarkan Undang-undang No. 35 Tahun 2009 tentang Narkotika Bab XV ketentuan pidana, maka pidana Narkotika adalah:

1. Setiap orang yang tanpa hak atau melawan hukum enanam, memelihara, memiliki, menyimpan, menguasai, atau menyediakan Narkotika Golongan I dalam bentuk tanaman (Pasal 111).

2. Setiap orang yang tanpa hak atau melawan hukum memiliki, menyimpan, menguasai, atau menyediakan Narkotika Golongan I bukan tanaman (Pasal 112).

3. Setiap orang yang tanpa hak atau melawan hukum memproduksi, mengimpor, mengekspor, atau menyalurkan Narkotika Golongan I (Pasal 113).

4. Setiap orang yang tanpa hak atau melawan hukum menawarkan untuk dijual, menjual, membeli, menerima, menjadi perantara dalam jual beli, menukar, atau menyerahkan Narkotika Golongan I (Pasal 114).

5. Setiap orang yang tanpa hak atau melawan hukum membawa, mengirim, mengangkut, atau mentransito Narkotika Golongan I (Pasal 115).

6. Setiap orang yang tanpa hak atau melawan hukum menggunakan Narkotika Golongan I terhadap orang lain atau memberikan Narkotika Golongan I untuk digunakan orang lain (Pasal 116).

7. Setiap orang yang tanpa hak atau melawan hukum memiliki, menyimpan, menguasai, atau menyediakan Narkotika Golongan II (Pasal 117).

8. Setiap orang yang tanpa hak atau melawan hukum memproduksi, mengimpor, mengekspor, atau menyalurkan Narkotika Golongan II (Pasal 118).

9. Setiap orang yang tanpa hak atau melawan hukum menawarkan untuk dijual, menjual, membeli, menerima, menjadi perantara dalam jual beli, menukar, atau menyerahkan Narkotika Golongan II (Pasal 119).

10. Setiap orang yang tanpa hak atau melawan hukum membawa, mengirim, mengangkut, atau mentransito Narkotika Golongan II (Pasal 120). 
11. Setiap orang yang tanpa hak atau melawan hukum menggunakan Narkotika Golongan II terhadap orang lain atau memberikan Narkotika Golongan II untuk digunakan orang lain (Pasal 121).

12. Setiap orang yang tanpa hak atau melawan hukum memiliki, menyimpan, menguasai, atau menyediakan Narkotika Golongan III (Pasal 122).

13. Setiap orang yang tanpa hak atau melawan hukum memproduksi, mengimpor, mengekspor, atau menyalurkan Narkotika Golongan III (Pasal 123).

14. Setiap orang yang tanpa hak atau melawan hukum menawarkan untuk dijual, menjual, membeli, menerima, menjadi perantara dalam jual beli, menukar, atau menyerahkan Narkotika dalam Golongan III (Pasal 124).

15. Setiap orang yang tanpa hak atau melawan hukum membawa, mengirim, mengangkut, atau mentransito Narkotika Golongan III (Pasal 125).

16. Setiap orang yang tanpa hak atau melawan hukum menggunakan Narkotika Golongan III terhadap orang lain atau memberikan Narkotika Golongan III untuk digunakan orang lain (Pasal 126).

17. Setiap Penyalahguna Narkotika Golongan I bagi diri sendiri, Narkotika Golongan II bagi diri sendiri, dan Narkotika Golongan III bagi diri sendiri (Pasal 127 Ayat (1)).

18. Pecandu Narkotika yang belum cukup umur (Pasal 55 Ayat (1)) yang sengaja tidak melapor (Pasal 128).

19. Setiap orang yang tanpa hak atau melawan hukum:

a. Memiliki, menyimpan, menguasai, atau menyediakan Prekursor Narkotika untuk pembuatan Narkotika;

b. Memproduksi, mengimpor, mengekspor, atau menyalurkan Prekursor Narkotika untuk pembuatan Narkotika;

c. Menawarkan untuk dijual, menjual, membeli, menerima, menjadi perantara dalam jual beli, menukar, atau menyerahkan prekursor Narkotika untuk pembuatan Narkotika;

d. Membawa, mengirim, mengangkut, atau mentransito prekursor Narkotika untuk pembuatan Narkotika, (Pasal 129).

Kajian tentang penggunaan saksi mahkota (kroongetuige) dalam pembuktian di persidangan terhadap tindak pidana narkotika dalam artikel ini dilakukan dengan menggunakan metode penelitian yuridis normatif. Pendekatan yang digunakan adalah perundang-undangan, konseptual dan kasus. Bahan hukum yang digunakan meliputi primer, sekunder dan tersier. Analisis dilakukan melalui tahapan interprestasi, nilai dan evaluasi.

\section{B. Metode Penelitian}

Dengan menggunakan metode yuridis normatif, Artikel ini menunjukkan penggunaan saksi mahkota (kroongetuige) dalam pembuktian di persidangan terhadap tindak pidana narkotika diterapkan untuk mencari dan mendapatkan kebenaran materil dalam perkara penyertaan, dan berkas perkara telah dipisah, serta terdapat kekurangan alat bukti keterangan saksi yang mengetahui secara terperinci tindak pidana yang dilakukan bersama-sama dan penggunaan saksi mahkota tergantung dari 
kebijakan hakim dan kekuatan saksi mahkota sebagai alat bukti dalam pembuktian tindak pidana narkotika.

C. Pembahasan

1. Penggunaan Saksi Mahkota (Kroongetuige) Dalam Pembuktian di Persidangan Terhadap Tindak Pidana Narkotika

a) Posisi Kasus

\section{1) Putusan Nomor $837 /$ Pid.Sus/2018/PN Jmb atas nama terdakwa Eko Wiji Mulyono Bin Katimin}

Bahwa Terdakwa Eko Wiji Mulyono Bin Katimin baik bertindak sendirisendiri maupun bersama-sama dalam suatu kesepakatan dengan Angga Marta Dinata Bin Zainudin (terdakwa dalam penuntutan terpisah) dan Sony Saputra Bin Harun (terdakwa dalam penuntutan terpisah) pada hari Minggu tanggal 02 September 2018 sekitar pukul 05.30 WIB atau setidak-tidaknya pada waktu lain dalam bulan September 2018 bertempat di rumah kontrakan yang terletak Didaerah Karya Kelurahan Sipin, Kecamatan Telanaipura Kota Jambi dan kosan BERKAH kamar nomor 03 lorong angkasa Kelurahan Paal Lima, Kecamatan Kota Baru Kota Jambi atau setidak-tidaknya pada suatu tempat yang masih termasuk dalam daerah hukum Pengadilan Negeri Jambi yang berwenang untuk memeriksa dan mengadili perkara tersebut, dengan percobaan atau permufakatan jahat tanpa hak atau melawan hukum menawarkan untuk dijual, menjual, membeli, menjadi perantara dalam jual beli, menukar, menyerahkan, atau menerima Narkotika Golongan I dalam bentuk bukan tanaman beratnya melebihi 5 (lima) gram.

\section{2) PutusanNomor 838/Pid.Sus/2018/PN Jmb atas nama terdakwa Angga Marta Dinata Bin Zainudin}

Bahwa Terdakwa Angga Marta Dinata Bin Zainudin baik bertindak sendiri-sendiri maupun bersama-sama dalam suatu kesepakatan dengan Sony Saputra Bin Harun (terdakwa dalam penuntutan terpisah) dan Eko Wiji Mulyono Bin Katimin (terdakwa dalam penuntutan terpisah) pada hari Jumat tanggal 17 Agustus 2018 sekira pukul 14.00 WIB, pada hari rabu tanggal 22 Agustus 2018 sekira pukul $10.00 \mathrm{WIB}$, pada hari selasa tanggal 28 Agustus 2018 sekira pukul 14.00 WIB, pada hari sabtu tanggal 01 September 2018 dan pada Minggu tanggal 02 September 2018 sekitar pukul 05.30 WIB atau setidak-tidaknya pada waktu lain dalam tahun 2018 bertempat didaerah telanaipura kota Jambi, diloket travel PIPOS jalan Hos Cokroaminoto Kel. Suka Karya, Kec. Kota Baru, Kota Jambi, didepan PDAM BRONI, dilorong TAC Sipin Kota Jambi dan di kosan BERKAH kamar nomor 03 lorong angkasa Kelurahan Paal Lima, Kecamatan Kota Baru Kota Jambi atau setidak-tidaknya pada suatu tempat yang masih termasuk dalam daerah hukum Pengadilan Negeri Jambi yang berwenang untuk memeriksa dan mengadili perkara tersebut, dengan percobaan atau permufakatan jahat tanpa hak atau melawan hukum menawarkan untuk dijual, menjual, membeli, menjadi perantara dalam jual beli, menukar, menyerahkan, atau menerima Narkotika Golongan I dalam bentuk bukan tanaman beratnya melebihi 5 (lima) gram. 


\section{3) Putusan Nomor 839/Pid.Sus/2018/PN Jmb atas nama terdakwa Sony Saputra Bin Harun}

Bahwa Terdakwa Sony Saputra Bin Harun baik bertindak sendiri-sendiri maupun bersama-sama dalam suatu kesepakatan dengan Angga Martadinata Bin Zainudin (terdakwa dalam penuntutan terpisah) dan Eko Wiji Mulyono Bin Katimin (terdakwa dalam penuntutan terpisah) pada hari Jumat tanggal 17 Agustus 2018 sekira pukul 14.00 WIB, pada hari rabu tanggal 22 Agustus 2018 sekira pukul 10.00 WIB, pada hari selasa tanggal 28 Agustus 2018 sekira pukul 14.00 WIB, pada hari sabtu tanggal 01 September 2018 dan pada Minggu tanggal 02 September 2018 sekitar pukul 05.30 WIB atau setidak-tidaknya pada waktu lain dalam tahun 2018 bertempat didaerah telanaipura kota Jambi, diloket travel PIPOS jalan Hos Cokroaminoto Kel. Suka Karya, Kec. Kota Baru, Kota Jambi, didepan PDAM BRONI, dilorong TAC Sipin Kota Jambi dan di kontrakan BERKAH kamar nomor 03 lorong angkasa Kelurahan Paal Lima, Kecamatan Kota Baru Kota Jambi atau setidak-tidaknya pada suatu tempat yang masih termasuk dalam daerah hukum Pengadilan Negeri Jambi yang berwenang untuk memeriksa dan mengadili perkara tersebut, dengan percobaan atau permufakatan jahat tanpa hak atau melawan hukum menawarkan untuk dijual, menjual, membeli, menjadi perantara dalam jual beli, menukar, menyerahkan, atau menerima Narkotika Golongan I dalam bentuk bukan tanaman beratnya melebihi 5 (lima) gram.

\section{4) Fakta-Fakta Hukum}

Terdakwa Angga mengenal terdakwa Sony melalui Farida (Bibi terdakwa Angga) yang mengatakan kepada terdakwa Angga jika ingin memesan narkotika agar melalui Sony yang saat itu sedang berada dilapas kelas IIA Jambi lalu Farida memberikan nomor hp Sony, sejak saat itu Angga sering berkomunikasi dengan Sony baik melalui sambungan telepon, pesan singkat maupun melalui aplikasi whatsapp berupa chatting dan video call.

Angga sudah 2 (dua) kali menghubungi Sony untuk membeli narkotika jenis shabu, selanjutnya Sony memerintahkan agar Angga mengambil paket milik Sony diloket travel PIPOS lalu mengambil 1 (satu) kotak kardus kecil yang didalam kotak terdapat 4 (empat) bungkus plastik yang berisikan narkotika jenis ekstasi warna merah muda dengan jumlah keseluruhan 400 (empat ratus butir) yang disimpan dikontrakan yang ditempati bersama Eko selanjutnya Angga sudah 2 (dua) kali disuruh Sony mengantarkan narkotika jenis ekstasi.

Selanjutnya Angga pergi bersama Eko dan Tobi (DPO) ke Grand Hotel untuk mendengarkan house music diperjalanan Angga memberikan ekstasi kepada EKO lalu mereka pulang selanjutnya Angga kembali keluar lalu pergi ke Salon \& Karaoke DINI untuk mendengarkan House music kembali sambil mengkonsumsi ekstasi. Selanjutnya anggota Tim Opsnal Sat Resnarkoba polresta Jambi melakukan penyelidikan atas informasi dari masyarakat bahwa tempat itu sering dijadikan tempat penyalahgunaan narkotika.

Tim Opsal melihat gerak gerik mencurigakan layaknya orang yang sedang dalam pengaruh narkotika dan selanjutnya Angga di interogasi kemudian mengakui dirinya baru saja mengkonsumsi ekstasi lalu di lakukan penggeledahan dan ditemukan 2 (dua) unit hp merk nokia dan merk xiomi. Dalam hp merk xiomi tersimpan percakapan antara Angga dan Sony yang mengarah pada pemesanan 
narkotika jenis ekstasi lalu ditanyakan keberadaan ekstasi tersebut dan mengakui menyimpan di rumah.

Selanjutnya menuju ke rumah dan saat sampai tim Opsnal mengamankan dan menginterogasi Eko yang mengakui baru saja memindahkan ekstasi ke sebuah kosan Berkah di Kota Baru selanjutnya tim Opsnal bersama Angga dan Eko pergi menuju kesana dan saat sampai Eko menunjukan tempat penyimpanan didalam sebuah tas koper dan menemukan 336 (tiga ratus tiga puluh enam butir) pil ektasi warna merah muda yang terbagi dalam 4 (empat) bungkusan plastik yang dimasukan dalam kotak celana dalam merk GT-MAN yang diakui oleh Angga keseluruhan tersebut adalah milik Sony yang sengaja dititipkan kepada Angga untuk dijual kepada pelanggan selanjutnya Angga dan Eko dibawa ke kantor polresta jambi sedangkan terhadap Sony dilakukan penjemputan dilapas untuk proses hukum lebih lanjut.

\section{b) Dakwaan Jaksa Penuntut Umum}

Dasar pembuatan surat dakwaan harus berpedoman dari berita acara pemeriksaan yang sudah dikualifikasi tindak pidananya oleh penyidik. Dalam membuat surat dakwaan yang harus di perhatikan adalah hasil pemeriksaan dan pasal tindak pidana yang dilanggar, jaksa penuntut umum yang membuat surat dakwaan dan melakukan tugas penuntutan berdasarkan berita acara yang diberikan oleh penyidik untuk dilanjutkan ke tahap pemeriksaan di sidang pengadilan.

a. Dakwaan pada Putusan Nomor 837/Pid.Sus/2018/PN Jmb atas nama terdakwa Eko Wiji Mulyono Bin Katimin:

2. Dakwaan Pertama Pasal 114 ayat (2) Jo. Pasal 132 ayat (1) UndangUndang RI Nomor 35 Tahun 2009 Tentang Narkotika.

3. Dakwaan Kedua Pasal 112 ayat (2) Jo. Pasal 132 ayat (1) UndangUndang RI Nomor 35 Tahun 2009 Tentang Narkotika.

b. Dakwaan pada Putusan Nomor 838/Pid.Sus/2018/PN Jmb atas nama terdakwa Angga Marta Dinata Bin Zainudin:

1. Dakwaan Pertama Pasal 114 ayat (2) Jo. Pasal 132 ayat (1) UndangUndang RI Nomor 35 Tahun 2009 Tentang Narkotika.

2. Dakwaan Kedua Pasal 112 ayat (2) Jo. Pasal 132 ayat (1) UndangUndang RI Nomor 35 Tahun 2009 Tentang Narkotika.

c. Dakwaan pada Putusan Nomor 839/Pid.Sus/2018/PN Jmb atas nama terdakwa Sony Saputra Bin Harun:

1. Dakwaan Pertama Pasal 114 ayat (2) Jo. Pasal 132 ayat (1) UndangUndang RI Nomor 35 Tahun 2009 Tentang Narkotika.

2. Dakwaan Kedua Pasal 112 ayat (2) Jo. Pasal 132 ayat (1) UndangUndang RI Nomor 35 Tahun 2009 Tentang Narkotika.

3. Dakwaan Ketiga Pasal 127 ayat (1) huruf a Undang-Undang RI Nomor 35 Tahun 2009 Tentang Narkotika.

\section{c) Alat Bukti}

a. Alat Bukti yang digunakan dalam Putusan Nomor 837/Pid.Sus/2018/PN

Jmb atas nama terdakwa Eko Wiji Mulyono bin Katimin berupa:

1) Keterangan saksi dari Fachrul Rozi, Muchtadin Nugraha, Sony Saputra bin Harun, dan Angga Marta Dinata.

2) Surat berupa: 
(1) Berita Acara Pemeriksaan tertanggal 03 September 2018 oleh Petugas PT. Pegadaian (persero) Cabang Jambi dan diperoleh hasil berat Bersih adalah 104,00 gram;

(2) Surat Keterangan Pengujian dari Balai POM Jambi No: PM.01.05.881.09.18.2414 tanggal 06 September 2018 yang pada kesimpulannya menerangkan bahwa contoh yang diterima dilab mengandung MDMA (bukan tanaman) dan termasuk Narkotika Golongan 1 (satu) pada lampiran Undang-Undang Nomor 35 Tahun 2009 tentang narkotika;

(3) Berita acara pemeriksaan hasil printout handphone milik Angga Martadinata tertanggal 19 September 2018.

3) Petunjuk diperoleh dari keterangan saksi, surat, dan keterangan terdakwa.

4) Keterangan Terdakwa Eko Wiji Mulyono.

b. Alat Bukti yang digunakan dalam Putusan Nomor 838/Pid.Sus/2018/PN Jmb atas nama terdakwa Angga Marta Bin Zainudin berupa:

1) Keterangan saksi dari Fachrul Rozi, Muchtadin Nugraha, Sony Saputra bin Harun, dan Eko Wiji Mulyono.

2) Surat berupa:

(1) Berita Acara Pemeriksaan tertanggal 03 September 2018 oleh Petugas PT. Pegadaian (persero) Cabang Jambi dan diperoleh hasil berat Bersih adalah 104,00 gram;

(2) Surat Keterangan Pengujian dari Balai POM Jambi No: PM.01.05.881.09.18.2414 tanggal 06 September 2018 yang pada kesimpulannya menerangkan bahwa contoh yang diterima dilab mengandung MDMA (bukan tanaman) dan termasuk Narkotika Golongan 1 (satu) pada lampiran Undang-Undang Nomor 35 Tahun 2009 tentang narkotika;

(3) Berita acara pemeriksaan hasil printout handphone milik Angga Martadinata tertanggal 19 September 2018.

3) Petunjuk diperoleh dari keterangan saksi, surat, dan keterangan terdakwa.

4) Keterangan Terdakwa Angga Marta Dinata.

c. Alat Bukti yang digunakan dalam Putusan Nomor 839/Pid.Sus/2018/PN Jmb atas nama terdakwa Sony Saputra bin Harun berupa:

1) Keterangan saksi dari Fachrul Rozi, Muchtadin Nugraha, Angga Marta Dinata, Eko Wiji Mulyono, Wellyam dan Agus saputra.

2) Surat berupa:

(1) Berita Acara Pemeriksaan tertanggal 03 September 2018 oleh Petugas PT. Pegadaian (persero) Cabang Jambi dan diperoleh hasil berat Bersih adalah 104,00 gram;

(2) Surat Keterangan Pengujian dari Balai POM Jambi No: PM.01.05.881.09.18.2414 tanggal 06 September 2018 yang pada kesimpulannya menerangkan bahwa contoh yang diterima dilab mengandung MDMA (bukan tanaman) dan termasuk Narkotika Golongan 1 (satu) pada lampiran Undang-Undang Nomor 35 Tahun 2009 tentang narkotika;

(3) Urinalisis nomor : R/834/IX/2018/Rumkit tanggal 03 September 2018 yang dibuat dan ditandatangani oleh dr. Arnella Hutagalung, 
dokter pada Rumah Sakit Bhayangkara Polda Jambi menyatakan hasil pemeriksaan urine tedakwa POSITIF mengandung Amphetamine dan Metamphetamine.

(4) Berita acara pemeriksaan hasil printout handphone milik Angga Martadinata tertanggal 19 September 2018.

3) Petunjuk diperoleh dari keterangan saksi, surat, dan keterangan terdakwa.

4) Keterangan Terdakwa Sony Saputra bin Harun.

\section{d. Keterangan Sebagai Saksi}

Keterangan Angga Marta Bin Zainudin sebagai terdakwa pada Putusan Nomor 838/Pid.Sus/2018/PN Jmb dan saksi Putusan Nomor 837/Pid.Sus/2018/PN Jmb dan dan Putusan Nomor 839/Pid.Sus/2018/PN Jmb sama dimana Angga pergi ke Salon \& Karaoke DINI untuk mendengarkan House music sambil mengkonsumsi ekstasi, selanjutnya Tim Opsal menginterogasi lalu mengakui dirinya baru saja mengkonsumsi ekstasi lalu dilakukan penggeledahan dan ditemukan 2 (dua) unit hp. Dalam hp merk xiomi tersimpan percakapan antara Angga dan Sony yang mengarah pada pemesanan ekstasi dan ekstasi tersebut disimpan dikontrakan yang ditempati bersama Eko.

Selanjutnya menuju ke rumah dan saat sampai tim Opsnal mengamankan dan menginterogasi Eko yang mengakui baru saja memindahkan ekstasi ke sebuah kosan Berkah di Kota Baru selanjutnya menuju kesana dan saat sampai Eko menunjukan tempat penyimpanan didalam sebuah tas koper dan menemukan 336 (tiga ratus tiga puluh enam butir) pil ektasi warna merah muda yang terbagi dalam 4 (empat) bungkusan plastik yang dimasukan dalam kotak celana dalam merk GT-MAN yang diakui oleh Angga keseluruhan tersebut adalah milik Sony yang sengaja dititipkan kepada Angga untuk dijual kepada pelanggan. Dan Angga tidak pernah bertemu Sony namun sering berkomunikasi baik melalui sambungan telepon, pesan singkat maupun melalui aplikasi whatsapp berupa chatting dan video call.

Dan mendapatkan ekstasi dari Sony yang memerintahkan Angga mengambil paket milik Sony diloket travel PIPOS lalu mengambil 1 (satu) kotak kardus kecil yang didalam kotak terdapat 4 (empat) bungkus plastik yang berisikan narkotika jenis ekstasi warna merah muda dengan jumlah keseluruhan 400 (empat ratus butir) selanjutnya Angga sudah 2 (dua) kali disuruh Sony mengantarkan narkotika jenis ekstasi namun tidak bertemu langsung dengan pelanggan dan sudah 2 (dua) kali menghubungi Sony untuk membeli narkotika jenis shabu.

Angga melihat dan membenarkan hasil print out pembicaraan antaranya dengan Sony dan membenarkan foto profil Sony di whatsapp sama dengan wajah Sony saat Angga melihat langsung dan mengenali suara Sony dalam persidangan sama dengan suara saat berkomunikasi melalui telepon.

Dan Angga diminta Sony untuk mengantarkan ekstasi dilapas kelas IIA Jambi untuk diberikan kepadanya yang akan dititipkan kepada petugas lapas namun dibatalkan karena sedang ada kepala lapas sehingga ekstasi Angga bawa pulang kembali. Dan Angga belum mendapat bayaran berupa uang dalam menjualkan ekstasi namun mendapat ekstasi sebanyak 5 butir yang di ambil dari ekstasi milik Sony.

Dan Angga tidak pernah menyuruh Eko untuk memindahkan ekstasi tetapi pernah menyampaikan bila ekstasi tersebut adalah milik Sony, dan pernah memberikan ekastasi milik Sony sebanyak $1 / 4$ butir kepada Eko untuk dikonsumsi. Dan menjual ekstasi atas perintah Sony melalui telepon serta tidak memiliki izin dalam menjual maupun memiliki narkotika jenis ekstasi dari pejabat yang berwenang. 


\section{e. Tuntutan Jaksa Penuntut Umum}

Jaksa penuntut umum memohon kepada Majelis Hakim Pengadilan Negeri Jambi yang mengadili dan memeriksa perkara ini untuk memutuskan Terdakwa Eko, Angga dan Sony yang di periksa secara terpisah sebagai berikut:

a. Tuntutan pada Putusan Nomor 837/Pid.Sus/2018/PN Jmb atas nama terdakwa Eko Wiji Mulyono bin Katimin:

1. Menyatakan Terdakwa EKO WIJI MULYONO Bin KATIMINtelah terbukti secara sah dan meyakinkan bersalah melakukan tindak Pidana "dengan percobaan atau permufakatan jahat tanpa hak atau melawan hukum menawarkan untuk dijual, menjual, membeli, menjadi perantara dalam jual beli, menukar, menyerahkan, atau menerima Narkotika Golongan I dalam bentuk bukan tanaman beratnya melebihi 5 (lima) gram"sebagaimana dalam dakwaan PERTAMA Jaksa Penuntut Umum;

2. Menjatuhkan pidana terhadap Terdakwa EKO WIJI MULYONO Bin KATIMIN dengan pidana penjara selama 7 (tujuh) tahun dengan ketentuan masa penahanan yang telah dijalani terdakwa dikurangkan seluruhnya dan denda sebesar Rp. 1.500.000.000,- (satu milyar lima ratus juta rupiah) subsidiair 6 (enam) bulan penjara;

3. Memerintahkan agar terdakwa tetap ditahan;

4. Menyatakanbarang bukti berupa:

- 336 (tiga ratus tiga puluh enam) butir narkotika jenis pil ekstasi warna merah muda;

- 7 (tujuh) plastik klip bening ukuran sedang bekas pembungkus pil ekstasi;

- 1 (satu) buah kotak celana dalam merk GT-MAN;

- 1 (satu) buah tas koper warna cokelat merk Polo England;

- 1 (satu) unit HP merk OPPO;

digunakan dalam perkara an. terdakwa ANGGA MARTA DINATA Bin ZAINUDIN;

5. Menetapkan agar terdakwa membayar biaya perkara sebesar Rp. 2000,(dua ribu rupiah).

b. Tuntutan pada Putusan Nomor 838/Pid.Sus/2018/PN Jmb atas nama terdakwa Angga Marta Din:

1. Menyatakan Terdakwa ANGGA MARTA DINATA Bin ZAINUDIN telah terbukti secara sah dan meyakinkan bersalah melakukan tindak Pidana "dengan percobaan atau permufakatan jahat tanpa hak atau melawan hukum menawarkan untuk dijual, menjual, membeli, menjadi perantara dalam jual beli, menukar, menyerahkan, atau menerima Narkotika Golongan I dalam bentuk bukan tanaman beratnya melebihi 5 (lima) gram"sebagaimana dalam dakwaan PERTAMA Jaksa Penuntut Umum;

2. Menjatuhkan pidana terhadap Terdakwa ANGGA MARTA DINATA Bin ZAINUDIN dengan pidana penjara selama 8 (delapan) tahun dengan ketentuan masa penahanan yang telah dijalani terdakwa dikurangkan seluruhnya dan denda sebesar Rp. 1.500.000.000,- (satu milyar lima ratus juta rupiah) subsidiair 6 (enam) bulan penjara; 
3. Memerintahkan agar terdakwa tetap ditahan;

4. Menyatakanbarang bukti berupa:

- 1 (satu) unit HP merk Nokia;

- 1 (satu) unit HP merk Xiomi;

- 336 (tiga ratus tiga puluh enam) butir narkotika jenis pil ekstasi warna merah muda;

- 7 (tujuh) plastik klip bening ukuran sedang bekas pembungkus pil ekstasi;

- 1 (satu) buah kotak celana dalam merk GT-MAN;

- 1 (satu) buah tas koper warna cokelat merk Polo England;

- 1 (satu) unit HP merk OPPO;

Digunakan dalam perkara an. terdakwa SONY SAPUTRA Bin HARUN;

5. Menetapkan agar terdakwa membayar biaya perkara sebesar Rp. 2000,(dua ribu rupiah).

c. Tuntutan pada Putusan Nomor 839/Pid.Sus/2018/PN Jmb atas nama terdakwa Sony Saputra bin Harun:

1. Menyatakan Terdakwa SONY SAPUTRA Bin HARUN telah terbukti secara sah dan meyakinkan bersalah melakukan tindak Pidana "dengan percobaan atau permufakatan jahat tanpa hak atau melawan hukum menawarkan untuk dijual, menjual, membeli, menjadi perantara dalam jual beli, menukar, menyerahkan, atau menerima Narkotika Golongan I dalam bentuk bukan tanaman beratnya melebihi 5 (lima) gram"sebagaimana dalam dakwaan PERTAMA Jaksa Penuntut Umum;

2. Menjatuhkan pidana terhadap Terdakwa SONY SAPUTRA Bin HARUN dengan pidana penjara selama 10 (sepuluh) tahun dengan ketentuan masa penahanan yang telah dijalani terdakwa dikurangkan seluruhnya dan denda sebesar Rp. 1.500.000.000,- (satu milyar lima ratus juta rupiah) subsidiair 6 (enam) bulan penjara;

3. Memerintahkan agar terdakwa tetap ditahan;

4. Menyatakanbarang bukti berupa :

- 1 (satu) unit HP merk Nokia;

- 1 (satu) unit HP merk Xiomi;

- 4 (empat) lembar hasil print out pesan singkat whatsapp dari 1 (satu) unit HP merk Xiomi milik ANGGA MARTADINATA;

- 6 (enam) lembar hasil print out pesan singkat dari 1 (satu) unit HP merk Xiomi milik ANGGA MARTADINATA;

- 336 (tiga ratus tiga puluh enam) butir narkotika jenis pil ekstasi warna merah muda;

- 7 (tujuh) plastik klip bening ukuran sedang bekas pembungkus pil ekstasi;

- 1 (satu) buah kotak celana dalam merk GT-MAN;

- 1 (satu) buah tas koper warna cokelat merk Polo England;

- 1 (satu) unit HP merk OPPO;

Dirampas untuk dimusnahkan;

5. Menetapkan agar terdakwa membayar biaya perkara sebesar Rp. 2000,(dua ribu rupiah). 


\section{f. Pertimbangan Hakim}

Pertimbangan hukum Hakim Pengadilan Negeri Jambi yang memeriksa dan mengadili perkara Putusan Nomor 837/Pid.Sus/2018/PN Jmb dan Putusan Nomor 838/Pid.Sus/2018/PN Jmb dan Putusan Nomor 839/Pid.Sus/2018/PN Jmb yang diperiksa secara terpisah setelah menelusuri dan menganalisa berdasarkan fakta yuridis, fakta sosiologis, dan fakta-fakta yang diperoleh di depan persidangan berupa keterangan para saksi, surat, keterangan terdakwa, barang bukti, petunjuk dan alat bukti lainnya yang saling bersesuaian.

Dengan menimbang bahwa Terdakwa Eko, Angga dan Sony yang di periksa secara terpisah telah didakwa oleh Penuntut Umum dengan dakwaan yang berbentuk alternatif, sehingga Majelis Hakim dengan memperhatikan fakta-fakta hukum tersebut memilih langsung dakwaan pertama perbuatan terdakwa diancam Pasal 114 ayat (2) Jo. Pasal 132 ayat (1) Undang-Undang RI Nomor 35 Tahun 2009 tentang Narkotika yang unsur-unsurnya adalah sebagai berikut:

1. Setiap orang;

2. Tanpa hak atau melawan hukum;

3. Percobaan atau pemufakatan jahat untuk menawarkan untuk di jual,menjual, membeli, menerima, menjadi perantara dalam jual beli, menukar, atau menyerahkan narkotika Golongan I dalam bentuk bukan tanamanan yang beratnya melebihi 5 (lima) gram;

Semua unsur telah terpenuhi maka terdakwa haruslah dinyatakan telah terbukti secara sah dan meyakinkan melakukan tindak pidana sebagaimana didakwakan dalam dakwaan pertama Penuntut Umum. Dan dalam persidangan Majelis Hakim tidak menemukan hal-hal yang dapat menghapuskan pertanggungjawaban pidana, baik sebagai alasan pembenar dan atau alasan pemaaf, maka terdakwa harus mempertanggungjawabkan perbuatannya oleh karenanya harus dinyatakan bersalah dan dijatuhi pidana.

Terhadap lamanya pidana yang akan dijatuhkan kepada terdakwa, Majelis Hakim sependapat dengan Penuntut Umum dan Majelis Hakim mempunyai pertimbangan yang dikaitkan dengan tujuan pemidanaan adalah bukanlah merupakan suatu pembalasan atau penyiksaan terhadap perbuatan yang telah dilakukan oleh terdakwa, akan tetapi tujuan pemidanaan tersebut memiliki dua fungsi yakni Prevensi special dan prevensi general.

Dalam perkara ini terhadap Terdakwa telah dikenakan penangkapan dan penahanan yang sah, maka masa penangkapan dan penahanan tersebut harus dikurangkan seluruhnya dari pidana yang dijatuhkan danoleh karena Terdakwa ditahan dan penahanan terhadap Terdakwa dilandasi alasan yang cukup, maka perlu ditetapkan agar Terdakwa tetap berada dalam tahanan dan terhadap barang bukti dimusnahkan.

Dalam menjatuhkan pidana terhadap Terdakwa maka perlu dipertimbangkan terlebih dahulu keadaan yang memberatkan dan yang meringankanTerdakwa:

Keadaaan yang memberatkan :

- Perbuatan terdakwa tidak mendukung program pemerintah dalam menangulangi Pemberantasan Narkotika.

Keadaan yang meringankan :

- Terdakwa bersikap sopan dipersidangan;

- Terdakwa berterus terang dipersidangan; 
- $\quad$ Terdakwa menyesali perbuatannya;

- $\quad$ Terdakwa berjanji tidak mengulangi lagi.

\section{g. Amar Putusan}

Pengadilan Negeri Jambi yang berkompeten menyidangkan dan memeriksa perkara tindak pidana sebagaimana telah dikemukakan diatas, sesuai dengan peraturan perundang-undangan yang berlaku dan telah menjatuhkan putusan.

a. Amar pada Putusan Nomor 837/Pid.Sus/2018/PN Jmb atas nama terdakwa Eko Wiji Mulyono bin Katimin:

\section{MENGADILI :}

1. Menyatakan Terdakwa Eko Wiji Mulyono bin Katimin tersebut diatas terbukti secara sah dan meyakinkan bersalah melakukan tindak pidana "Pemufakatan Jahat melakukan perbuatan tanpa hak atau melawan hukum menjadi perantara dalam jual beli narkotika golongan I dalam bentuk bukan tanaman yang beratnya melebihi 5 (lima) gram" sebagaimana dalam dakwaan pertama;

2. Menjatuhkan pidana kepada Terdakwa oleh karena itu dengan pidana penjara selama6 (enam) tahun dan denda Rp. 1.000.000.000,00 (satu milyar rupiah), dengan ketentuan apabila denda tersebut tidak dibayar diganti dengan pidana penjara selama 1 (satu) bulan;

3. Menetapkan masa penangkapan dan penahanan yang telah dijalani Terdakwa dikurangkan seluruhnya dari pidana yang dijatuhkan;

4. Menetapkan Terdakwa tetap ditahan;

5. Menetapkan barang bukti berupa:

- 336 (tiga ratus tiga puluh enam) butir narkotika jenis pil ekstasi warna merah muda;

- 7 (tujuh) plastik klip bening ukuran sedang bekas pembungkus pil ekstasi;

- 1 (satu) buah kotak celana dalam merk GT-MAN;

- 1 (satu) buah tas koper warna cokelat merk Polo England;

- 1 (satu) unit HP merk OPPO;

Dikembalikan kepada Penuntut Umum untuk dipergunakan dalam perkara atas nama terdakwa Angga Marta Dinata;

6. Membebankan kepada Terdakwa membayar biaya perkara sejumlah Rp 5.000,00 (lima ribu rupiah).

b. Amar pada Putusan Nomor 838/Pid.Sus/2018/PN Jmb atas nama terdakwa Angga Marta Dinata bin Zainudin:

\section{MENGADILI :}

1. Menyatakan Terdakwa Angga Marta Dinata bin Zainudin tersebut diatas terbukti secara sah dan meyakinkan bersalah melakukan tindak pidana "Pemufakatan Jahat melakukan perbuatan tanpa hak atau melawan hukum menjadi perantara dalam jual beli narkotika golongan I dalam bentuk bukan tanaman yang beratnya melebihi 5 (lima) gram" sebagaimana dalam dakwaan pertama;

2. Menjatuhkan pidana kepada Terdakwa oleh karena itu dengan pidana penjara selama6 (enam) tahun dan 6 (enam) bulan dan denda Rp. 1.000.000.000,00 (satu milyar rupiah), dengan ketentuan apabila denda 
tersebut tidak dibayar diganti dengan pidana penjara selama 1 (satu) bulan;

3. Menetapkan masa penangkapan dan penahanan yang telah dijalani Terdakwa dikurangkan seluruhnya dari pidana yang dijatuhkan;

4. Menetapkan Terdakwa tetap ditahan;

5. Menetapkan barang bukti berupa:

- 1 (satu) unit HP merk Nokia;

- 1 (satu) unit HP merk Xiomi;

- 336 (tiga ratus tiga puluh enam) butir narkotika jenis pil ekstasi warna merah muda;

- 7 (tujuh) plastik klip bening ukuran sedang bekas pembungkus pil ekstasi;

- 1 (satu) buah kotak celana dalam merk GT-MAN;

- 1 (satu) buah tas koper warna cokelat merk Polo England;

- 1 (satu) unit HP merk OPPO;

Dikembalikan kepada Penuntut Umum untuk dipergunakan dalam perkara atas nama terdakwa Sony Saputra bin Harun;

6. Membebankan kepada Terdakwa membayar biaya perkara sejumlah Rp 5.000,00 (lima ribu rupiah).

c. Amar pada Putusan Nomor 839/Pid.Sus/2018/PN Jmb atas nama terdakwa Sony Saputra bin Harun:

\section{MENGADILI :}

1. Menyatakan Terdakwa Sony Saputra bin Harun tersebut diatas terbukti secara sah dan meyakinkan bersalah melakukan tindak pidana "Pemufakatan Jahat melakukan perbuatan tanpa hak atau melawan hukum menjadi perantara dalam jual beli narkotika golongan I dalam bentuk bukan tanaman yang beratnya melebihi 5 (lima) gram" sebagaimana dalam dakwaan pertama;

2. Menjatuhkan pidana kepada Terdakwa oleh karena itu dengan pidana penjara selama 8 (delapan) tahun dan dan denda Rp. 1.500.000.000,00 (satu milyar lima ratus juta rupiah), dengan ketentuan apabila denda tersebut tidak dibayar diganti dengan pidana penjara selama 1 (satu) bulan;

3. Menetapkan Terdakwa tetap ditahan;

4. Menetapkan barang bukti berupa:

- 1 (satu) unit HP merk Nokia;

- 1 (satu) unit HP merk Xiomi;

- 4 (empat) lembar hasil print out pesan singkat whatsapp dari 1 (satu) unit HP merk Xiomi milik ANGGA MARTADINATA;

- 6 (enam) lembar hasil print out pesan singkat dari 1 (satu) unit HP merk Xiomi milik ANGGA MARTADINATA;

- 336 (tiga ratus tiga puluh enam) butir narkotika jenis pil ekstasi warna merah muda;

- 7 (tujuh) plastik klip bening ukuran sedang bekas pembungkus pil ekstasi;

- 1 (satu) buah kotak celana dalam merk GT-MAN; 
- 1 (satu) buah tas koper warna cokelat merk Polo England;

- 1 (satu) unit HP merk OPPO;

Dimusnahkan;

5. Membebankan kepada Terdakwa membayar biaya perkara sejumlah Rp 5.000,00 (lima ribu rupiah).

\section{h. Analisis Penulis}

Hakim dalam memeriksa suatu perkara tindak pidana tidak boleh menyimpang dari apa yang dirumuskan di dalam surat dakwaan. Terdakwa hanya dapat dijatuhkan hukuman karena telah dibuktikan dalam persidangan bahwa terbukti secara sah dan meyakinkan bersalah melakukan tindak pidana narkotika seperti dalam surat dakwaannya sehingga berhasilnya suatu proses penegakan hukum bergantung pada penerapan hukum pidana dimana peran penegak hukum dalam pelaksanaannya menjadi salah satunya.

Penggunaan Saksi Mahkota (Kroongetuige) terdapat dalam Surat Edaran Kejaksaan Agung Republik Indonesia No. B-69/E/02/1997 yang menyatakan saksi mahkota digunakan dalam hal terjadi penyertaan dan dengan pertimbangan bahwa dalam status sebagai terdakwa, keterangannya hanya berlaku untuk dirinya sendiri, oleh karena itu dengan berpedoman pada pasal 142 KUHAP, maka berkas perkara harus diadakan pemisahan (splitsing), agar para terdakwa dapat disidangkan terpisah, sehingga terdakwa yang satu dapat menjadi saksi terhadap terdakwa lainnya.

Dan disisi lain juga masih terdapat kekurangan alat bukti keterangan saksi yang membuktikan kesalahan terdakwa, oleh karenanya untuk kepentingan pembuktian terdapat cukup alasan untuk didengar keterangan saksi mahkota dalam perkara tindak pidana narkotika yang dilakukan bersama-sama namun tetap ditambah dengan alat bukti lainnya.

Dalam perkara di atas dapat dilihat penyertaan dimana telah terjadi perbuatan permufakatan jahat tanpa hak atau melawan hukum menawarkan untuk dijual, menjual, membeli, menjadi perantara dalam jual beli, menukar, menyerahkan, atau menerima Narkotika Golongan I dalam bentuk bukan tanaman beratnya melebihi 5 (lima) gram.

Dan perkara tindak pidana narkotika tersebut telah dilakukan pemisahan berkas perkara sesuai dengan kebutuhan serta pada saat proses pemeriksaan dihadirkannya saksi mahkota tidak ada keberatan dari pihak penasihat hukum terdakwa yang mengetahui penggunaan saksi mahkota, oleh karenanya tidak ada permasalahan dalam proses pemeriksaan saksi mahkota tersebut sehingga terdakwa Angga Marta Dinata Bin Zainudin dapat dijadikan saksi terhadap perkara tindak pidana Eko Wiji Mulyono Bin Katimin dan Sony Saputra Bin Harun.

Dalam proses pemeriksaan di sidang Pengadilan Negeri Jambi terhadap perkara tindak pidana narkotika, terdakwa Angga Marta Dinata Bin Zainudin dijadikan saksi mahkota untuk bisa mengadili terdakwa Eko Wiji Mulyono Bin Katimin dan Sony Saputra Bin Harun karena mengetahui secara terperinci tentang perencanaan, persiapan, dan proses pelaksanaan sehingga terjadi tindak pidana yang dilakukan bersama-sama seperti yang didakwakan oleh jaksa penuntut umum.

Dalam kesaksian Angga Marta Dinata Bin Zainudin membenarkan bahwa ia dan para terdakwa lainnya telah melakukan tindak pidana narkotika. Dan guna membentuk keyakinan hakim bahwa terbukti telah terjadi tindak pidana dan terdakwalah yang 
melakukannya, serta adanya keyakinan hakim terdakwa bersalah tanpa terbukti adanya peniadaan pidana sehingga terdakwa dapat dipidana diperlukan tambahan alat bukti jenis lain untuk menguatkan keterangan yang diberikan saksi mahkota tersebut.

Dalam proses pemeriksaan di sidang Pengadilan Negeri Jambi terhadap perkara tindak pidana narkotika diatas sudah memenuhi 2 (dua) alat bukti yang sah. Dan mengenai syarat satu orang saksi bukan saksi (Unus Testis Nullus Testis) sudah terpenuhi dimana dalam perkara diatas terdapat beberapa saksi lain, tetapi disini tetap masih diperlukan keterangan saksi mahkota yang mengetahui secara terperinci mengenai tindak pidana yang dilakukan bersama-sama untuk mencari dan mendapatkan kebenaran materil oleh karenanya disini saksi mahkota dapat dijadikan hakim sebagai petunjuk dalam memutus perkara tindak pidana narkotika.

\section{Kekuatan Pembuktian Mahkota sebagai Alat Bukti dalam Pembuktian Tindak Pidana Narkotika}

Syarat-syarat yang harus dipenuhi agar alat bukti keterangan saksi mempunyai kekuatan dalam pembuktian yaitu saksi dinyatakan sah sebagai alat bukti keterangan saksi, keterangan saksi dinyatakan di sidang pengadilan harus mengenai peristiwa pidana yang di dengar, di lihat, dan di alami sendiri, sebelum memberikan keterangan saksi wajib mengucapkan sumpah atau janji menurut cara agamanya bahwa akan memberikan keterangan yang sebenar-benarnya, keterangan seorang saksi saja dianggap tidak cukup, agar mempunyai kekuatan pembuktian maka harus ditambah dan dicukupi dengan alat bukti lainnya, dan keterangan para saksi yang dihadirkan dalam sidang pengadilan mempunyai hubungan atau keterkaitan serta saling menguatkan tentang kebenaran suatu keadaan atau kejadian.

Pada prinsipnya sebagai terdakwa dapat mengingkari apa yang sebenarnya terjadi serta tidak mempermasalahkan dirinya sendiri apabila memberikan keterangan sebagai terdakwa dalam berkas perkaranya karena mempunyai hak ingkar. Apabila diperlukan terdakwa dapat dihadirkan sebagai saksi karena kurangnnya alat bukti keterangan saksi, jika keterangan yang diberikan terdakwa sebagai saksi berbeda dengan keterangannya sebagai terdakwa maka keterangannya sebagai saksi itu dapat dikenakan sumpah palsu.

Keterangan saksi mahkota tetap membutuhkan penilaian dan pertimbangan hakim untuk menentukan apakah saksi mahkota dapat dijadikan alat bukti saksi yang sah dan mempunyai nilai serta kekuatan pembuktian, karena saksi mahkota yang pada dasarnya seorang terdakwa dan juga saksi tidak mempunyai kekuatan pembuktian yang sempurna dan mengikat hakim sehingga hakim mempunyai kebebasan untuk menilainya.

Pada proses pemeriksaan di sidang Pengadilan Negeri Jambi dalam perkara tindak pidana narkotika Eko Wiji Mulyono bin Katimin dan Sony Saputra bin Harun yang diperiksa secara terpisah menghadirkan terdakwa Angga Marta Dinata bin Zainudin sebagai saksi dalam perkara tindak pidana yang dilakukan bersama-sama disini hakim dituntut bersikap cermat, seksama, dan teliti karena saksi mahkota merupakan seorang terdakwa dan juga saksi.

Kesaksian yang diberikan terdakwa Angga Marta Dinata bin Zainudin sebagai saksidinyatakan didepan persidangan dengan mengucapkan sumpah terlebih dahulu dan dalam memberikan keterangan berterus-terang serta keterangan itu bersesuaian dengan keterangan saksi lain dan alat bukti lain dengan pertimbangan demikian 
keterangan yang diberikan mempunyai nilai dan kekuatan pembuktian sehingga dapat membuktikan bahwa telah terjadi tindak pidana dan terdakwalah yang melakukannya, serta adanya keyakinan hakim terdakwa sehingga terdakwa dapat dipidana.

Kekuatan Saksi Mahkota Sebagai Alat Bukti Dalam Pembuktian Tindak Pidana Narkotikamempunyai nilai kekuatan pembuktian bebas dimana tidak mempunyai kekuatan pembuktian sempurna, tidak menentukan dan tidak mengikat sehingga hakim dituntut bersikap cermat, seksama, dan teliti. Keterangan saksi mahkota mempunyai nilai kekuatan pembuktian apabila dinyatakan sah sebagai saksi, tidak ada keberatan dari pihak penasihat hukum terdakwa mengenai kehadiran saksi mahkota dan keterangan dinyatakan di depan persidangan dimana telah di sumpah terlebih dahulu serta keterangan yang diberikan bersesuaian dengan keterangan yang diberikan saksi lain maupun alat bukti lain sehingga dapat membuktikan kesalahan terdakwa.

\section{Simpulan}

Artikel ini menyimpulkan pertama, penggunaan saksi mahkota (kroongetuige) dalam pembuktian di persidangan terhadap tindak pidana narkotika diterapkan untuk mencari dan mendapatkan kebenaran materil dalam perkara penyertaan, dan berkas perkara telah dipisah, serta terdapat kekurangan alat bukti keterangan saksi yang mengetahui secara terperinci tindak pidana yang dilakukan bersama-sama dan penggunaan saksi mahkota tergantung dari kebijakan hakim. Kedua, kekuatan saksi mahkota sebagai alat bukti dalam pembuktian tindak pidana narkotikamempunyai nilai kekuatan pembuktian apabila saksi mahkota dinyatakan sah sebagai alat bukti keterangan saksi dengan memberikan keterangan didepan persidangan dan telah disumpah terlebih dahulu serta keterangan yang diberikan bersesuaian dengan keterangan saksi lain maupun alat bukti lain serta ditambah dengan keyakinan hakim

\section{DAFTAR PUSTAKA}

\section{Dokumen Hukum}

Undang-Undang Nomor 8 Tahun 1981 tentang Hukum Acara Pidana (KUHAP)

\section{Buku}

Alfitra. Hukum Pembuktian Dalam Beracara Pidana, Perdata dan Korupsi Di Indonesia. Raih Asa Sukses, Jakarta, 2012.

Chazawi, Adami. Hukum Pembuktian Tindak Pidana Korupsi. P.T. Alumni, Bandung, 2008.

Hamzah, Andi. Hukum Acara Pidana Indonesia. Sinar Grafika, Jakarta, 2008.

Hartanti, Evi. Tindak Pidana Korupsi. Sinar Grafika, Jakarta, 2012.

Prasetyo, Teguh. Hukum Pidana. Rajawali Pers, Jakarta, 2015.

\section{Jurnal/Majalah Ilmiah}

Ante, Susanti. "Pembuktian Dan Putusan Pengadilan Dalam Acara Pidana”. Lex Crimen, Vol 2 No. 2, 2013. 
Nugroho, Bastianto. "Peranan Alat Bukti Dalam Perkara Pidana Dalam Putusan Hakim Menurut Kuhap". Jurnal Hukum Yuridika, Vol 32 No. 1, 2017.

Setiyawan, Wahyu Beny Mukti. "Analisis Keberadaan Saksi Mahkota Dalam Kasus Pembunuhan Nasrudin Zulkarnaen Sebagai Upaya Penegakan Hak Asasi Manusia Ditinjau Dari Kitab Undang-Undang Hukum Acara Pidana (KUHAP)". Jurnal Serambi Hukum, Vol 10 No. 02, 2017.

Usman dan Andi Najemi. "Mediasi Penal di Indonesia: Keadilan, Kemanfaatan, dan Kepastian Hukumnya". Jurnal Hukum, Vol 1 No. 1, 2018. 